\title{
Comparative profiling of the synaptic proteome from Alzheimer's disease patients with focus on the APOE genotype
}

Raphael Hesse ${ }^{1 \dagger}$, Maica Llavero Hurtado ${ }^{2 \dagger}$, Rosemary J. Jackson ${ }^{1 \dagger}$, Samantha L. Eaton ${ }^{2 \dagger}$, Abigail G. Herrmann ${ }^{1}$,

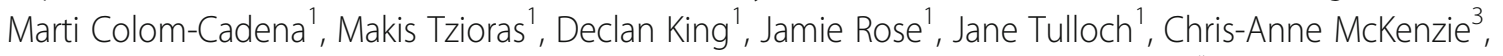
Colin Smith ${ }^{3}$, Christopher M. Henstridge ${ }^{1,4}$, Douglas Lamont ${ }^{5}$, Thomas M. Wishart ${ }^{2 *}$ and Tara L. Spires-Jones ${ }^{1 *}$ (D)

\begin{abstract}
Degeneration of synapses in Alzheimer's disease (AD) strongly correlates with cognitive decline, and synaptic pathology contributes to disease pathophysiology. We recently observed that the strongest genetic risk factor for sporadic AD, apolipoprotein E epsilon 4 (APOE4), is associated with exacerbated synapse loss and synaptic accumulation of oligomeric amyloid beta in human AD brain. To begin to understand the molecular cascades involved in synapse loss in $A D$ and how this is mediated by $A P O E$, and to generate a resource of knowledge of changes in the synaptic proteome in $A D$, we conducted a proteomic screen and systematic in silico analysis of synaptoneurosome preparations from temporal and occipital cortices of human $A D$ and control subjects with known APOE gene status. We examined brain tissue from 33 subjects (7-10 per group). We pooled tissue from all subjects in each group for unbiased proteomic analyses followed by validation with individual case samples. Our analysis identified over 5500 proteins in human synaptoneurosomes and highlighted disease, brain region, and APOE-associated changes in multiple molecular pathways including a decreased abundance in AD of proteins important for synaptic and mitochondrial function and an increased abundance of proteins involved in neuroimmune interactions and intracellular signaling.
\end{abstract}

Keywords: Alzheimer, Synapse, Apolipoporotein E, Proteomics

\section{Highlights}

- Proteomic analysis of synapses isolated from Alzheimer's disease and control subject brains identifies over 5500 proteins in human synapses.

- In silico analysis reveals region-specific decreases in proteins involved in synaptic and mitochondrial function and increases in proteins involved in neuroimmune signaling and intracellular signaling in $\mathrm{AD}$.

\footnotetext{
* Correspondence: T.M.Wishart@ed.ac.uk; Tara.spires-jones@ed.ac.uk ${ }^{\dagger}$ Raphael Hesse, Maica Llavero Hurtado, Rosemary J. Jackson and Samantha L. Eaton contributed equally to this work.

${ }^{2}$ College of Medicine and Veterinary Medicine, The Roslin Institute and Royal (Dick) School of Veterinary Studies, University of Edinburgh, Easter Bush, Midlothian EH25 9RG, Scotland, UK

${ }^{1}$ Centre for Discovery Brain Sciences, UK Dementia Research Institute, The University of Edinburgh, 1 George Square, Edinburgh EH8 9JZ, Scotland, UK Full list of author information is available at the end of the article
}

- The apolipoprotein E4 risk gene is associated with exacerbated changes in synaptic proteins in AD.

\section{Introduction}

Dementia poses one of the biggest societal challenges of the twenty-first century. Over 50 million people are living with dementia worldwide, it costs over $\$ 800$ billion per year to care for them, and there are currently no disease modifying treatments [54]. One of the barriers to developing effective therapies for Alzheimer's disease, the most common cause of dementia, lies in the lack of a comprehensive understanding of the brain changes that cause neurodegeneration. In particular, a key knowledge gap is not yet understanding how genetic risk factors contribute to disease pathogenesis [35]. Extracellular amyloid beta (A $\beta)$ plaques, intracellular neurofibrillary tangles composed of hyperphosphorylated tau protein, and severe brain atrophy are the major

(c) The Author(s). 2019 Open Access This article is distributed under the terms of the Creative Commons Attribution 4.0 International License (http://creativecommons.org/licenses/by/4.0/), which permits unrestricted use, distribution, and 
neuropathological hallmarks of AD [45]. There are many genetic risk factors for developing sporadic $\mathrm{AD}$, the strongest of which is inheritance of the apolipoprotein $\mathrm{E}$ epsilon 4 allele (APOE4). Inheritance of one copy of $A P O E 4$ is associated with a 3 fold increase in disease risk and inheritance of two copies with an over 10 fold increased risk [9]. In addition to its known roles in $A \beta$ production and clearance, we and others have observed that apoE protein accumulates in synapses $[3,22,27,50]$, which is important as synapse loss is the strongest pathological correlate with cognitive decline in $\operatorname{AD}[13,48,51]$. ApoE4 causes more synaptic loss around plaques when expressed in mouse models of familial AD [22]. Using high resolution imaging in human post-mortem brain tissue, we similarly observed exacerbated synapse loss in $A P O E 4$ carriers and further that apoE4 is associated with more accumulation of oligomeric $A ß$ at synapses [24, 27]. More recent data implicates APOE4 in tau mediated neurodegeneration [47] and also inflammatory TREM2 mediated microglial phenotypes [28], which may be important for synapse degeneration [52]. Further highlighting the importance of APOE to AD progression, the Christchurch mutation in $A P O E 3$ was recently observed to be associated with delayed disease onset in a person with a familial $\mathrm{AD}$ mutation in presenilin 1 [2] .

Recent data from postnatal human brain samples shows that proteomic datasets can reveal differences in proteins that are not observed in RNA expression data, arguing the importance of building strong resource datasets at the level of protein in human diseases [7]. Thus far there have been several proteomic studies of human $\mathrm{AD}$ brain tissue (Additional file 1: Table S1), but a comprehensive dataset on human synaptic proteins examining the effects of $A P O E$ genotype in $\mathrm{AD}$ remains unavailable.

In order to further our understanding of how $A P O E$ may be influencing synaptic vulnerability in $\mathrm{AD}$, we have performed a comprehensive proteomic study of human post-mortem brain tissue through a series of molecular comparisons allowing us to assess the relative contribution of both regional vulnerability and $A P O E$ variants to AD pathogenesis. Although our study is in postmortem tissue which has inherent limitations including looking at a snapshot of the end stage of the disease, the inclusion of a less affected brain region allows some novel insight into changes that may be occurring in synapses earlier in the degenerative process. We provide a unique proteomic resource identifying over 5500 proteins in human synaptoneurosome preparations. These preparations enrich remaining synapses in the brain and unlike examination of total homogenates allow specific examination of change in synaptic proteins without the confound of synapse loss [49]. Additionally, we highlight multiple proteins and molecular pathways that are modified in $\mathrm{AD}$ with brain region and $A P O E$ genotype status.
In silico analysis reveals that proteins involved in glutamatergic synaptic signalling and synaptic plasticity are decreased in AD with temporal cortex (which has high levels of pathology) being more severely affected than occipital cortex (which has lower levels of pathology) and APOE4 carriers more affected than APOE 3 carriers. Alterations in glial proteins important for neuroimmune signalling were also detected using in silico analysis, and further investigation revealed a host of proteins involved in the complement cascade are not only found in human synapses but are increased in AD compared to control brain. In addition to providing a resource for the field, our data support the hypothesis that $A P O E$ genotype plays an important role in synaptic dysfunction and degeneration in $\mathrm{AD}$. The proteins and pathways identified as altered in this study can in future be investigated in more detail for their potential as therapeutic intervention points to delay or prevent synaptic alterations and the consequential symptoms contributing to dementia.

\section{Methods \\ Subjects}

Use of human tissue for post-mortem studies has been reviewed and approved by the Edinburgh Brain Bank ethics committee and the ACCORD medical research ethics committee, AMREC (ACCORD is the Academic and Clinical Central Office for Research and Development, a joint office of the University of Edinburgh and NHS Lothian, approval number 15-HV-016). The Edinburgh Brain Bank is a Medical Research Council funded facility with research ethics committee (REC) approval (16/ES/0084).

Fresh frozen brain tissue for proteomics and paraffin embedded tissue for examination of pathology was provided from superior temporal gyrus (BA41/42) and primary visual cortex (BA17). Tissue was requested from clinically diagnosed $\mathrm{AD}$ and control subjects. All cases were examined by a neuropathologist, and after the proteomics results were returned, it was noted that one of the AD cases was neuropathologically classified as frotntotemporal dementia with tau-associated corticobasal degeneration (Table 1). The pooled design of the study precludes exclusion of this case post-hoc but also reduces interindividual heterogeneity $[25,36]$. However, pooled analyses on difficult sample types such as serum have also been reported to be associated with false positive and false negative results [37]. While this has not been a problem in any of our previous analyses of synaptically enriched fractions, it does highlight the need for validation of results.

\section{APOE genotyping}

DNA was extracted from $\sim 25 \mathrm{mg}$ of cerebellum for each case using the QIAamp DNA mini kit (Qiagen, Hilden, Germany), which was used as per the manufacturer's instructions. Polymerase chain reaction (PCR) was 


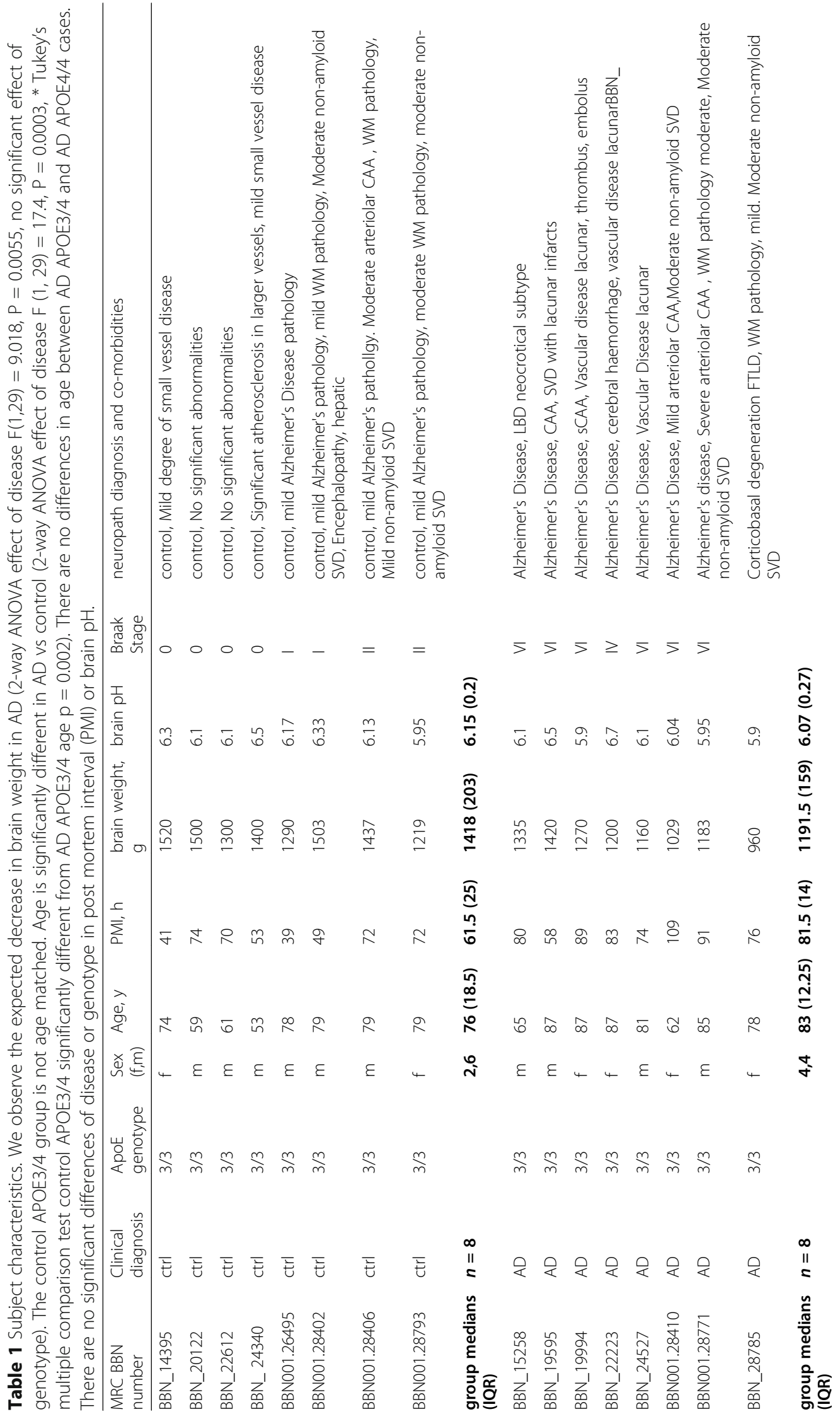


Hesse et al. Acta Neuropathologica Communications

(2019) 7:214

Page 4 of 18

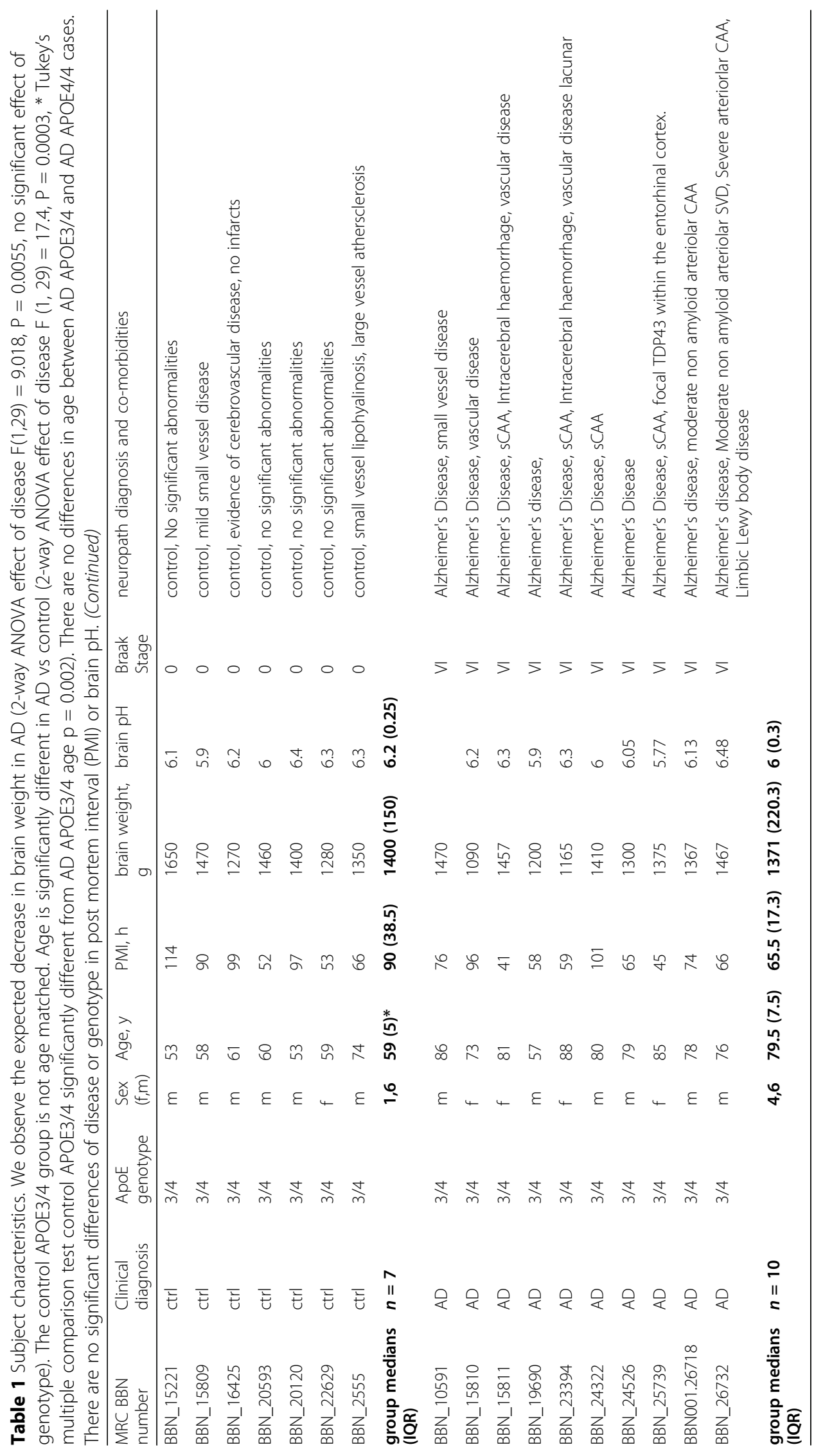


performed on the extracted DNA. $10 \mu \mathrm{l}$ of 2x Master mix (Promega, Madison, WI) was combined with $1 \mu \mathrm{l}$ of primer stock $(20 \mu \mathrm{M}$ forward primer, $20 \mu \mathrm{M}$ reverse primer), $2 \mu \mathrm{l}$ of DMSO (Sigma-Aldrich, St Louis, MO),

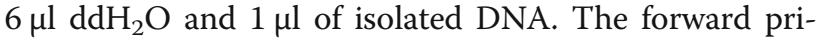
mer was 5'taagcttggcacggctgtccaagg3' and the reverse primer 5'acagaattcgccccggcctggtacactgcc3' (Fig. 2.2a). $A P O E \varepsilon 2, A P O E \varepsilon 3$, and $A P O E \varepsilon 4$ plasmids (generously donated by Dr. E Hudry) were also amplified by PCR to use at as reference and were treated in the same way as unknown samples throughout. PCR product was digested using the restriction endonuclease HhaI (New England Biolabs, Ipswich, MA). For this $0.5 \mu \mathrm{l}$ of enzyme, $2.5 \mu \mathrm{l}$ of 10x CutSmart buffer (New England Biolabs, Ipswich, MA) and $2 \mu \mathrm{l}$ of $\mathrm{dd}_{2} \mathrm{O}$ were added to each PCR reaction tube to give a total volume of $25 \mu \mathrm{l}$. The final volume contains $50 \mathrm{mM}$ Potassium Acetate, $20 \mathrm{mM}$ Tris-acetate, $10 \mathrm{mM}$ Magnesium Acetate, and $100 \mu \mathrm{g} / \mathrm{ml} \mathrm{BSA}$ as a result of the CutSmart buffer and 10 units of Hhal. After digestion incubation $5 \mu \mathrm{l}$ of $6 \mathrm{x}$ Blue Loading dye (Promega, Madison, WI) containing $0.4 \%$ orange $\mathrm{G}, 0.03 \%$ bromophenol blue, $0.03 \%$ xylene cyanol FF, $15 \%$ Ficoll $^{\circ} 400,10 \mathrm{mM}$ Tris- $\mathrm{HCl}$ (pH 7.5) and $50 \mathrm{mM}$ EDTA ( $\mathrm{pH} 8.0$ ) was added to the the reaction tube. $14 \mu \mathrm{l}$ of this mixture was then loaded onto precast 15 well Novex TBE 20\% gel (Thermo Fisher Scientific, Waltham, MA) using a $25 \mu \mathrm{L}$ Hamilton Syringe. The DNA were then separated by size using electrophoresis for $2 \mathrm{~h}$ at $200 \mathrm{~V}$. The gels were run in an XCell SureLock ${ }^{\mathrm{Tx}}$ Mini-Cell (Invitrogen, Carlsbad, CA) using Novex TBE running buffer (Thermo Fisher Scientific, Waltham, MA). Bands were stained with either $2 \mu \mathrm{g} / \mathrm{ml}$ ethidium bromide (Sigma-Aldrich, St Louis, MO) or SYBR safe DNA Gel Stain (Thermo Fisher Scientific, Waltham, MA) and visualized with an ultraviolet gel imaging system (Syngene, Cambridge, UK).

\section{Amyloid beta and tau staining in human cortical sections} Tissue sections were stained for amyloid beta and tau according to a previous study [17]. Briefly, fresh postmortem tissue blocks were fixed in formalin and dehydrated in an ascending alcohol series. Three paraffin waxing stages were performed and $4 \mu \mathrm{m}$ thick tissue sections were cut on a Leica microtome and collected on glass slides. Immunohistochemistry for amyloid beta (BA4, M087201-2, Agilent) and pTau (AT8, MN1020, Thermo) was performed using the Novolink Polymer detection system and visualized using DAB as chromogen. Images were acquired using an upright Zeiss axioImager equipped with MicroBrightfield stereology software.

\section{Synaptoneurosome preparation}

Brain homogenates and synaptic fractions were prepared as described in Tai et al. 2012 [49]. In brief,
$300 \mathrm{mg}$ of cortical tissue was homogenized on ice in homogenization buffer (25 mM HEPES pH 7.5, 120 $\mathrm{mM} \mathrm{NaCl}, 5 \mathrm{mM} \mathrm{KCl}, 1 \mathrm{mM} \mathrm{MgCl} 2,2 \mathrm{mM} \mathrm{CaCl}$, protease inhibitors (roche complete mini), phosphatase inhibitors (Millipore, 524,629)). The homogenate was filtered through 2 layers of $80 \mu \mathrm{m}$ nylon filter (Millipore, NY8002500) and saved as crude homogenate. The crude homogenate was further filtered through a $5 \mu \mathrm{m}$ filter (Millipore, SLSV025NB) and centrifuged at $1000 \mathrm{~g}$ for $5 \mathrm{~min}$. The pellet was washed once, then the supernatant was removed and the pellet was resuspended in in label-free buffer [100 mM Tris- $\mathrm{HCl}(\mathrm{pH}$ 7.6) 4\% (w/ v) SDS] containing $1 \%$ protease cocktail inhibitor (Thermo Fisher, UK). Homogenates were centrifuged at $20,000 \times \mathrm{g}$ for $20 \mathrm{~min}$ at $4{ }^{\circ} \mathrm{C}$ with the soluble fraction of each sample transferred to Lo-Bind tubes (Sigma Aldrich). Protein determination using the Bicinchoninic acid assay (Pierce, UK) was carried out according to manufacturer's guidelines.

\section{Electron microscopy}

Synaptoneurosome pellets were fixed in $4 \%$ paraformaldehyde/ $2 \%$ glutaraldehyde in PB for $48 \mathrm{~h}$ at $4{ }^{\circ} \mathrm{C}$. Pellets were then post fixed in $1 \%$ osmium tetroxide for $30 \mathrm{~min}$, rinsed, and dehydrated in increasing concentrations of ethanol with uranyl acetate $1 \%$ in the $70 \%$ ethanol step for $1 \mathrm{~h}$. After $100 \%$ ethanol, pellets were rinsed in propylene oxide then embedded in Durcupan resin per manufacterers instructions. $70 \mathrm{~nm}$ sections were cut on an Ultracut microtome (Leica) with a histo jumbo diamond knife (Diatome) and moutned on 300 mesh copper EM grids (Electron microscopy sciences). Sections were stained with lead citrate in a $\mathrm{CO}_{2}$ free environment for $2 \mathrm{~min}$, rinsed in boiled double distilled water, and imaged on a JOEL JEM-1400 transmission electron microscope at an effective magnification of 25,000x-50,000x.

\section{SDS-PAGE and western blotting}

SDS-PAGE and western blotting were performed as described previously [19]. Briefly, $5 \mu \mathrm{g}$ of protein from synaptoneurosome fractions and molecular weight marker (Li-Cor, Cambridge, UK) was loaded onto NuPAGE $4-12 \%$ Bis-Tris precast polyacrylamide 15 well gels (Invitrogen, Paisley, UK). Proteins were transferred to polyvinylidene fluoride (PDVF) membranes and blocked using Odyssey Blocking buffer (927-40,000, Li-Cor) diluted 1:1 in PBS. Primary antibodies were incubated overnight in blocking buffer and proteins were detected on an Odyssey system using 680 and 800 IR dye secondary antibodies diluted 1:10000 in blocking buffer (Table 2 shows antibodies used in western blots). Total protein stains were performed with Instant Blue total protein stain per manufacturer instructions (Expedeon). 
Table 2 Antibodies used for Western blots

\begin{tabular}{|c|c|c|c|c|}
\hline Protein & Manufacturer & Catalogue & Validation for WB (from manufacturers website) & RRID \\
\hline Actin & Abcam & AB 8226 & Cell lysates from HeLa, Jurkat, A431, HEK293, NIH 3 T3, PC12 cells. & AB_306371 \\
\hline Alpha synuclein & Santa Cruz & Sc-7011-R & SH-SY5Y cell lysate, a-synuclein expression in mouse and rat brain tissue extracts. & AB_2192953 \\
\hline Annexin V & Abcam & AB 54775 & ANXA5 expression in Hela, 293 T cell line, pentoxifylline cell treatment. & AB_940268 \\
\hline Beta Tubulin & Abcam & AB 18207 & $\begin{array}{l}\text { HAP1 cell lysate; mouse brain and hippocampus lysates; rat brain lysate; human } \\
\text { brain lysate. Knock out cell lines studies. }\end{array}$ & AB_444319 \\
\hline GAPDH & Abcam & AB 9845 & HeLa, A431, A549, NIH3T3, PC12 whole cell lysate & AB_307275 \\
\hline GFAP & Dako/Agilent & Z033429-2 & $\begin{array}{l}\text { antibody solid-phase absorbed with human and cow serum proteins. One distinct } \\
\text { precipitate (GFAP) with cow brain extract. }\end{array}$ & AB_10013382 \\
\hline Histone $\mathrm{H} 3$ & Abcam & Ab 1791 & $\begin{array}{l}\text { HeLa, Drosophila embryo nuclear extract, NIH/3 T3, S.cerevisiae (Y190) and S.pombe } \\
\text { whole cell }\end{array}$ & AB_302613 \\
\hline NMDANR2B & BD Biosciences & 610,416 & Rat NMDA receptors & AB_397796 \\
\hline PSD95 & Abcam & AB 18258 & Mouse and rat brain lysates. PSD95 knockout mouse and immunoprecipitation. & AB_444362 \\
\hline SNAP25 & Abcam & AB 53723 & RAW264.7 cell extracts and blocking peptides. & AB_882623 \\
\hline SOD2 & novusbio & NB100-1992 & Rat brain tissue extract. & AB_535862 \\
\hline Synaptophysin & Abcam & AB 8049 & Presynaptic vesicles. & AB_2198854 \\
\hline TMEM97 & Atlas Antibodies & HPA044795 & Recombinant expression validation using target protein overexpression. & AB_10959306 \\
\hline
\end{tabular}

WB Western blot, RRID Research Resource Identifiers

\section{LC-MS/MS analysis}

Pools containing equal amounts of protein $(25 \mu \mathrm{g}$ per case) were prepared of each of the 8 groups (control APOE3/3 BA41/42, control APOE3/3 BA17, control APOE3/4 BA41/42, control APOE3/4 BA17, $\mathrm{AD}$ APOE3/3 BA41/42, AD APOE3/3 BA17, AD APOE3/4 BA41/42, AD APOE3/4 BA17). Preparation of the samples, quantification, and bioinformatics was carried out according to standardized protocols $[15,25,32]$.

Samples were lysed in $4 \%$ SDS $+100 \mathrm{mM}$ tris prior to protein estimation by microBCA. Each sample was then reduced with $100 \mathrm{mM}$ DTT and samples then processed using the FASP protocol [56] with some modifications. Samples were initially diluted 1:10 into $8 \mathrm{M}$ Urea and buffer exchanged to remove the SDS and tris buffer, filters were then washed 3 times with $100 \mathrm{mM}$ Tris-HCL $\mathrm{pH} 8$ then another 3 times with $100 \mathrm{mM}$ triethyl ammonium bicarbonate (TEAB). Proteins on the filters are then digested twice at 30oc with trypsin $(2 \times 1 \mu \mathrm{g})$, first overnight and then for another $6 \mathrm{~h}$ in a final volume of $200 \mu \mathrm{l}$ prior to addition of $200 \mathrm{ul}$ of $500 \mathrm{mM} \mathrm{NaCl}$. Samples were then desalted using a SPE cartridge (Empore-C18, Agilent Technologies, $7 \mathrm{~mm} / 3 \mathrm{ml}$ ) and the peptides dried in a speedvac (Savant).

Desalted tryptic peptides ( $25 \mu \mathrm{g}$ each sample) were then dissolved in $100 \mu \mathrm{l} 100 \mathrm{mM}$ TEAB. The different 8 TMT labels were dissolved in $41 \mu \mathrm{L}$ of anhydrous acetonitrile, and each label then added to a different sample. The mixtures were incubated for $1 \mathrm{~h}$ at room temperature and the labelling reaction was then quenched by adding $8 \mu \mathrm{L}$ of $5 \%$ hydroxylamine. Following labelling with TMT, samples were mixed, desalted using a SPE cartridge
(Empore-C18, Agilent Technologies, $7 \mathrm{~mm} / 3 \mathrm{ml}$ ) and the peptides dried in a speedvac (Savant). Samples were then dissolved in $200 \mu \mathrm{L}$ ammonium formate $(10 \mathrm{mM}, \mathrm{pH} 10)$ and peptides fractionated using High $\mathrm{pH}$ RP HPLC. A C18 Column from Waters (XBridge peptide BEH, $130 \AA$, $3.5 \mu \mathrm{m} 2.1 \times 150 \mathrm{~mm}$, Ireland) with a guard column (XBridge, C18, $3.5 \mu \mathrm{m}, 2.1 \mathrm{X} 10 \mathrm{~mm}$, Waters) are used on a Ultimate 3000 HPLC (Thermo-Scientific). Buffers A and $B$ used for fractionation consists, respectively of $10 \mathrm{mM}$ ammonium formate in milliQ water and $10 \mathrm{mM}$ ammonium formate with $90 \%$ acetonitrile, both buffers were adjusted to $\mathrm{pH} 10$ with ammonia. Fractions were collected using a WPS-3000FC auto-sampler (Thermo-Scientific) at 1 min intervals. Column and guard column were equilibrated with $2 \%$ buffer B for 20 min at a constant flow rate of $0.2 \mathrm{ml} / \mathrm{min}$. Samples $(175 \mu \mathrm{l})$ were loaded onto the column at $0.2 \mathrm{ml} / \mathrm{min}$. Peptides were eluted from the column with a gradient of $2 \%$ buffer B to $5 \% \mathrm{~B}$ in $6 \mathrm{~min}$ then from $5 \% \mathrm{~B}$ to $60 \% \mathrm{~B}$ in $50 \mathrm{~min}$. The column is washed for 16 min at $100 \%$ buffer B and equilibrated at $2 \%$ buffer B for $20 \mathrm{~min}$ as mentioned above. The fraction collection started $1 \mathrm{~min}$ after injection and stopped after $80 \mathrm{~min}$ (total of 80 fractions, $200 \mu \mathrm{l}$ each). The total number of fractions concatenated was set to 20 by non-contiguous pooling and the content of the fractions dried and resuspended in $50 \mu \mathrm{l}$ of $1 \%$ formic acid prior to analysis by nLC-MS/MS.

Analysis of peptides was performed using a QExactive-HF (Thermo Scientific) mass spectrometer coupled with a UltiMate 3000 RSLCnano (Thermo Scientific) UHPLC system. nLC buffers were as follows: buffer A ( $2 \%$ acetonitrile and $0.1 \%$ formic acid 
in Milli-Q water $(\mathrm{v} / \mathrm{v}))$ and buffer B $(80 \%$ acetonitrile and $0.08 \%$ formic acid in Milli-Q water $(\mathrm{v} / \mathrm{v})$. Aliquots of $15 \mu \mathrm{L}$ of each sample (50ul in total) were loaded at $5 \mu \mathrm{L} / \mathrm{min}$ onto a trap column $(100 \mu \mathrm{m} \times 2$ $\mathrm{cm}$, PepMap nanoViper C18 column, $5 \mu \mathrm{m}, 100 \AA$, Thermo Scientific) equilibrated in $98 \%$ buffer A. The trap column was washed for $6 \mathrm{~min}$ at the same flow rate and then the trap column was switched in-line with a Thermo Scientific, resolving C18 column $(75 \mu \mathrm{m} \times 50 \mathrm{~cm}$, PepMap RSLC C18 column, $2 \mu \mathrm{m}$, $100 \AA$ ). The peptides were eluted from the column at a constant flow rate of $300 \mathrm{nl} / \mathrm{min}$ with a linear gradient from $95 \%$ buffer A to $40 \%$ buffer B in 122 min, and then to $98 \%$ buffer B by $132 \mathrm{~min}$. The column was then washed with $95 \%$ buffer B for $15 \mathrm{~min}$ and re-equilibrated in $98 \%$ buffer A for $32 \mathrm{~min}$. QExactive HF was used in data dependent mode. A scan cycle comprised MS1 scan (m/z range from 335 to 1800 , with a maximum ion injection time of 50 ms, a resolution of 120,000 and automatic gain control (AGC) value of $3 \times 106)$ followed by 15 sequential dependant MS2 scans (with an isolation window set to $0.7 \mathrm{Da}$, resolution at 60000 , maximum ion injection time at $200 \mathrm{~ms}$ and AGC $1 \times 105$. To ensure mass accuracy, the mass spectrometer was calibrated on the first day that the runs are performed.

The raw mass spectrometric data files obtained for each experiment were collated into a single quantitated dataset using MaxQuant 1.6.0.16 [10] and Andromeda search engine software [11] with enzyme specificity set to trypsin. Other parameters used were: (i) variable modifications, deamidation $(\mathrm{NQ})$, oxidation $(\mathrm{M})$, protein $\mathrm{N}$-acetylation, gln-pyro-glu; (ii) fixed modifications, carbamidomethylation (C); (iii) database: uniprot-human Sept2017 database; (iv) Reporter ion MS2 - TMT labels: TMT8plex_Nter and TMT 8plex-Lys; (v) MS/MS tolerance: FTMS- $10 \mathrm{ppm}$, ITMS- $0.02 \mathrm{Da}$; (vi) maximum peptide length, 6; (vii) maximum missed cleavages, 2; (viii) maximum of labelled amino acids, 3 ; and (ix) false discovery rate, $1 \%$. Peptide ratios were calculated using 'Reporter Intensity' Data that was normalised using 1/ median ratio value for each identified protein group per labelled sample.

\section{In silico analyses}

Filtered data was utilised for all bioinformatics statistical analyses and filtered by the following excluding proteins identified by only 1 peptide. For some analyses we filtered for proteins that demonstrated a $\pm>20 \%$ change between $A P O E 3 / 4 \mathrm{BA} 41 / 42 \mathrm{AD}$ and control subjects. The Database for Annotation Visualization and Integrated Discovery (DAVID) was used to test whether synaptic protein sets were enriched in the samples [21]. To obtain further insight into potential pathways changed in $\mathrm{AD}$ synapses, Ingenuity Pathway Analysis (IPA, Ingenuity Systems) was used as previously described [15, 32, 55] with the interaction data limited as follows: direct and indirect interactions; experimentally observed data only; 35 molecules per network; 10 networks per dataset. Prediction activation scores ( $\mathrm{z}$ - scores) were calculated in IPA. Expression clustering was performed in Biolayout Express 3D software by applying Markov clustering algorithms to raw proteomic data (MCL 19 2.2) as previously described in [32]. All graphs were clustered using Pearson correlation $r=0.96$.

\section{Data sharing}

Unfiltered proteomics data is included as Additional file 5: Table S5. The mass spectrometry proteomics data have also been deposited to the ProteomeXchange Consortium via the PRIDE partner repository [39], with the dataset identifier PXD013753. DAVID analysis is provided in Additional file 2: Table S2. The full IPA analysis from Fig. 3 is in Additional file 3: Table S3. Complement proteins identified are in Additional file 4: Table S4. Filtered proteomics data used for IPA analysis in Fig. 3 is provided in Additional file 6: Table S6.

\section{Results \\ Development of a human post-mortem synaptic reference proteome}

To better understand the changes in synapses that may contribute to disease pathogenesis in $\mathrm{AD}$ and how the genetic risk factor $A P O E$ contributes to synaptic vulnerability, we conducted a proteomic study of human post-mortem brain tissue. Using immunohistochemistry, proteomics, and western blots, we examined two brain regions, superior temporal gyrus (BA41/42) which has a severe pathological burden and primary visual cortex (BA17) which is less severely affected even at the end stages of disease (Fig. 1a and b) [45]. With this study design incorporating disease, brain region, and $A P O E$ genotype, it is possible to design a series of comparisons which will enable the interrogation of complex proteomic comparisons in a biologically meaningful way (Fig. 1c). Through the MRC Edinburgh sudden death brain bank, we were able to access samples from 33 brain tissue donors whose condition and underlying genetics were amenable to this particular investigation. Details of subjects in the study can be found in Table 1 .

Synaptic fractions were prepared and quality control for post-mortem protein degradation were confirmed as previously described [15, 25, 32] (Fig. 2). Enrichment of synaptic proteins and exclusion of nuclear protein were confirmed by western blot (Fig. 2a). Any synaptoneurosome preparations containing nuclear histone protein 


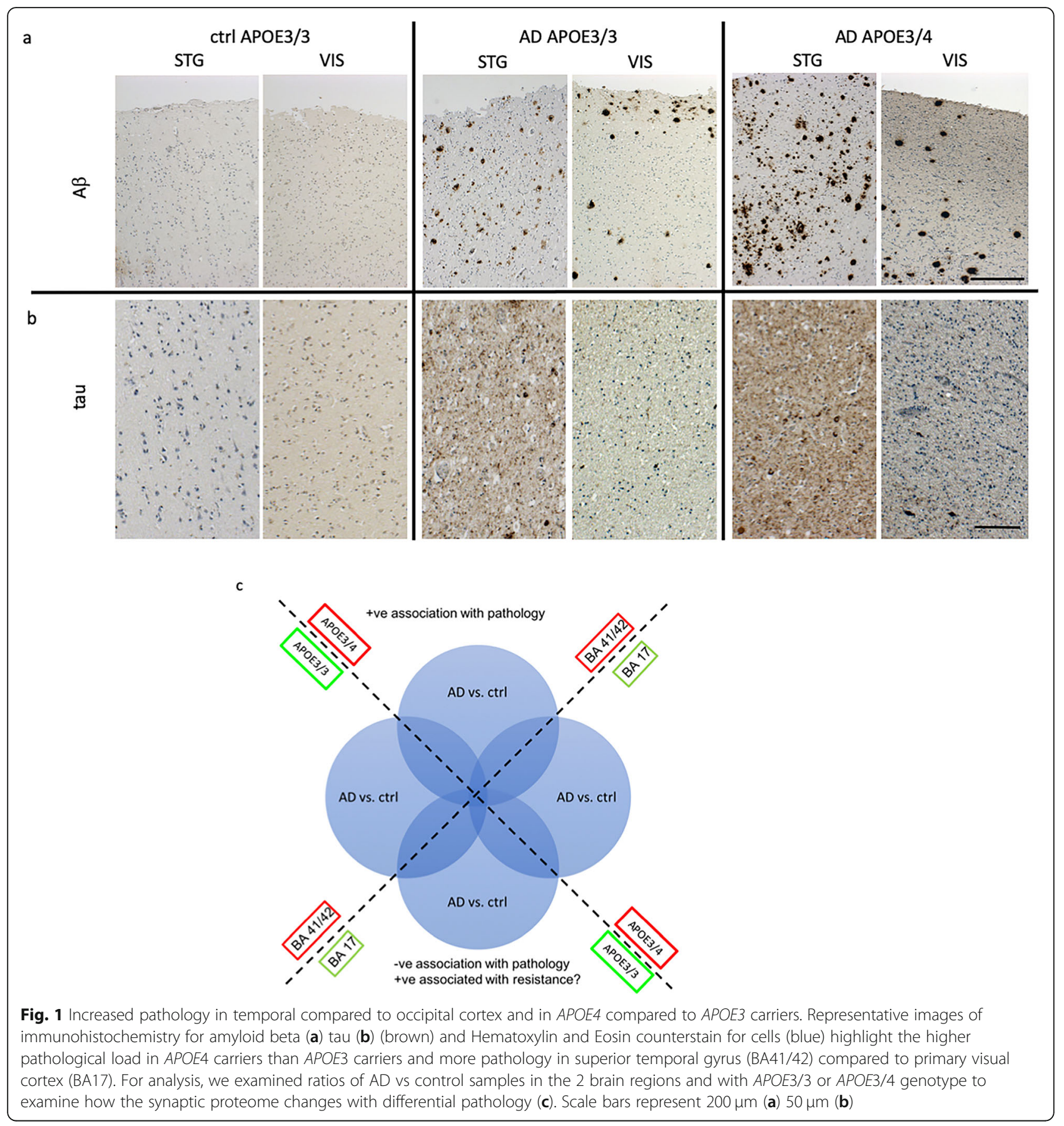

were discarded and fresh preparations made from the same case. Protein degradation was assessed using comparison of total protein stains (Fig. 2b-d) and using the "HUSPIR" ratio which examines NMDAR2B degradation that occurs postmortem [6] (Additional file 8: Figure S2). The HUSPIR ratio significantly correlated with RNA integrity number $\left(p=0.009, R^{2}=0.215\right.$, linear regression analysis $)$ and brain $\mathrm{pH}\left(p=0.023, R^{2}=0.184\right.$, linear regression analysis) but not at all with post-mortem interval.
RIN and pH are routinely collected for all brain bank samples and used as a proxy for tissue integrity. Here we confirm that protein degradation correlates better with these markers than with post-mortem interval highlighting the importance of tissue handling in maintaining protein integrity. Electron microcopy conducted on synaptoneurosome pellets (Fig. 2e) confirms preservation of pre and postsynaptic terminals in pairs with our synaptoneurosome preparation as we had previously observed [49]. We 

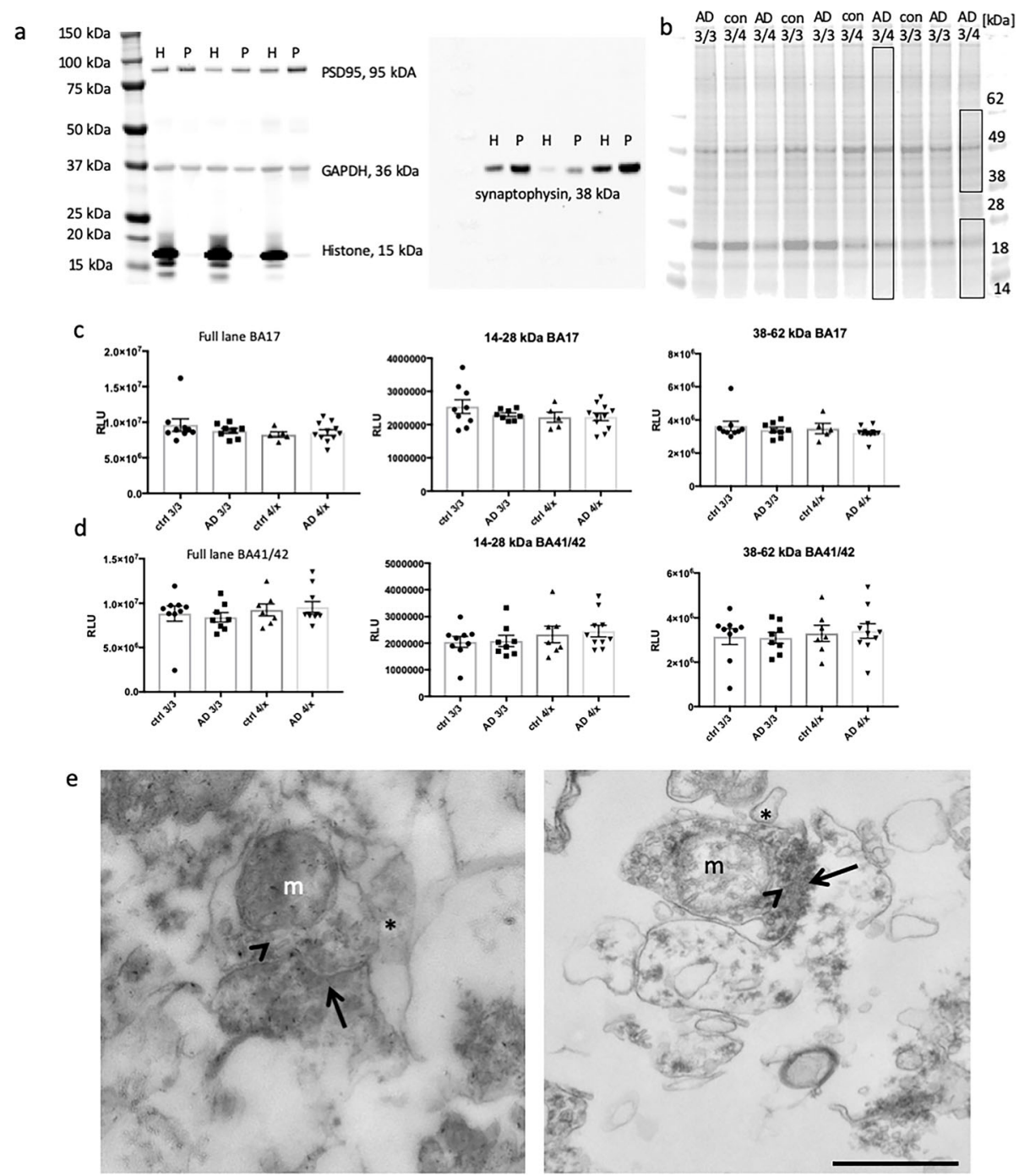

Fig. 2 Enrichment and integrity analysis of synaptic protein preparations a) A representative western blot from 3 cases shows the enrichment of synaptic proteins and exclusions of histones from the synaptoneurosome preparation (P) compared to crude homogenate $(H)$ protein from that sample. Blots were probed for PSD95, synaptophysin, histone and GAPDH. b Total protein analysis (TPA) was also used to determine whether any samples showed evidence of protein degradation. Boxes in panel (b) indicate the molecular weight ranges analysed for total protein stain. Quantification reveals no difference in total protein in BA17 (c) or BA41/42 (d) samples (One way ANOVAs, $p>0.05$ ). Transmission electron microscopy confirms that synaptoneurosome preparations contain paired pre and post synaptic terminals as expected (e). We observe clear electron dense postsynaptic densities (arrows), presynaptic vesicles (arrowheads), presynaptic mitochondria (m) and small processes associated with synapses $\left(^{*}\right)$. Scale bar represents $500 \mathrm{~nm}$

observe clear post synaptic densities, presynaptic vesicles, and synaptic mitochondria.

Having confirmed that the extracted protein is of appropriate quality, we then applied a comprehensive workflow to enable us to assess (at the protein level) the relative contribution of both regional vulnerability and $A P O E$ variants as a risk factors to $\mathrm{AD}$ pathogenesis (Fig. 1c, Additional file 7: Figure S1) [15, 32]. We performed a complex 8-plex TMT LC-MS/MS analysis. Representative pools based on the outlined groupings were generated from these synaptic protein extracts. By pooling individual samples according to $A P O E$ genotype and cortical area, we were able to reduce potential noise in the system generated through inter individual differences, subtle post mortem handling differences and/or sample isolation [16]. Thus, $25 \mu \mathrm{g}$ of each of the 33 subjects were pooled according to disease status, $A P O E$ genotype (3/3 or $3 / 4)$ and brain region (BA41/42 or BA17). The inclusion of an equivalent proportion of each protein isolate into a readily comparable pool allowed the generation of a molecular fingerprint representative of each condition and enables subsequent analysis of individual patient variability in the resulting validatory work 
(as a deviation from the population signal, as previously described $[25,36])$.

Following detection on the mass spectrometer, quantitation of the dataset using MaxQuant [10] and Andromeda search engine software [11] we identified 7148 protein identifications (IDs) in total. These 7148 identified proteins were then filtered to include only proteins identified by 2 or more unique peptides (Fig. 3c). This yielded 5678 proteins. A DAVID enrichment analysis of this filtered list of proteins served to further confirmed enrichment of the samples for synaptic material (Additional file 2: Table S2).

Having confirmed that the proteomic data is likely to be representative of the synaptically enriched starting material we then filtered to include only those demonstrating differential abundance of equal to or greater $20 \%$ (up or down regulated) in the comparison $\mathrm{AD}$ vs. ctrl in BA41/42 in APOE4 carriers (Fig. 3). After applying these further two data filtering steps we obtained a set of 1532 protein IDs identified with high confidence and meeting our differential abundance criteria.

In order to validate the proteomics data, we selected a subset of 9 proteins for western blot analysis in BA41/42 whose levels should be increased or decreased just past our magnitude of change cutoff as this will be more indicative of the sensitivity of the MS than highly up or downregulated proteins. We also selected a protein whose levels was unchanged to use as an internal control (Fig. 3, Additional file 9: Figure S3) [44]. All of the proteins we chose for validation by western blot went in the direction indicated by the proteomics results and the ratios of $\mathrm{AD} /$ non-demented control levels in western blots significantly correlated with those found with proteomics (Pearson's correlation $p=0.03$, details in Fig. 3).

\section{In silico analysis revealed differences in abundance ratios correlating with increasing vulnerability for $A D$ neuropathology}

To determine potential differences in the synaptic proteomes of AD patients vs. control subjects dependent on $A P O E$ genotype and brain region, we focused on the protein abundance ratios as calculated by dividing values from $\mathrm{AD}$ patients by matched control subjects, subcategorised for $A P O E 3 / 4$ or $A P O E 3 / 3$ genotype, and segregated by brain region (Fig. 3a-c). More proteins were changed in AD patients compared to controls in BA41/42 of APOE4 carriers than any other condition (Fig. $3 \mathrm{~b}$ ). The numbers of protein changes increases progressively from $A P O E 3 / 3 \mathrm{BA} 17<$ $A P O E 3 / 3 \quad \mathrm{BA} 41 / 42<A P O E 3 / 4 \quad \mathrm{BA} 17<A P O E 3 / 4$ BA41/42. Looking at the 15 most upregulated and downregulated pathways detected by Ingenuity
Pathway Analysis software (Fig. 4) reveals that pathways involved in intracellular signalling, glial proteins involved in glia-neuron interactions, and the immune response are upregulated in $\mathrm{AD}$ compared to control with generally larger effects in the temporal cortex BA41/42. Downregulated pathways include many involved in synaptic function such as synaptic long term potentiation, glutamate signalling, and calcium signalling. The most downregulated pathway in $\mathrm{AD}$ APOE3/4 BA/41/42 was oxidative phosphorylation including significant downregulation of proteins in complex I, IV, and V. This pathway was increased in BA17 indicating a potential compensatory effect in BA17 which has less pathology at end stages of disease. This combination of region specific decreases in synaptic and mitochondrial proteins is very interesting in light of our recent paper showing decreased numbers of mitochondria in synaptic terminals in BA41/ 42 using electron microscopy [40]. All pathways detected with IPA analysis are available in Additional file 3: Table S3.

Our previous work examining synapses in human post-mortem tissue has revealed that the handling of the body and the tissue is critical for maintaining structural and molecular integrity of synapses $[26,40]$. In particular, we observe that rapid cooling of the body after death preserves synapse structure and molecular integrity better even than short post-mortem intervals. Therefore in this study we used samples only from the Edinburgh MRC Sudden Death Brain Bank whose robust handling protocol is carried out on each individual ensuring that the data is as comparable as possible. This precluded precise age and sex matching of our control groups with our AD groups (see Table 1), which could mean that there are confounding effects of age and sex on our $\mathrm{AD} /$ control comparisons. However, when we compare BA41/42 of the AD APOE3/4 to AD APOE3/3 cases, which are better age and sex matched, we observe many of the same pathways increased in AD APOE4 carriers compared to $\mathrm{AD} A P O E 3$ carriers as those we observed in the comparison of $\mathrm{AD}$ vs control APOE4 carriers (Fig. 4). Less changes were observed in BA17 from $\mathrm{AD} A P O E 4$ carriers compared to $\mathrm{AD} A P O E 3$ carriers. This strongly supports our conclusion that $A P O E 4$ influences the synaptic proteome in $\mathrm{AD}$ in a region-specific manner. Interestingly, in non-demented controls when APOE4 carriers are compared to APOE3 carriers in BA41/ 42 , there are changes in the opposite direction to those that are observed in APOE4 AD vs control.

To further examine trends in protein changes in an unbiased manner, we performed clustering analysis to detect differences in the abundance ratios across these differentially vulnerable synaptic populations. Proteins were clustered according to their abundance profile 


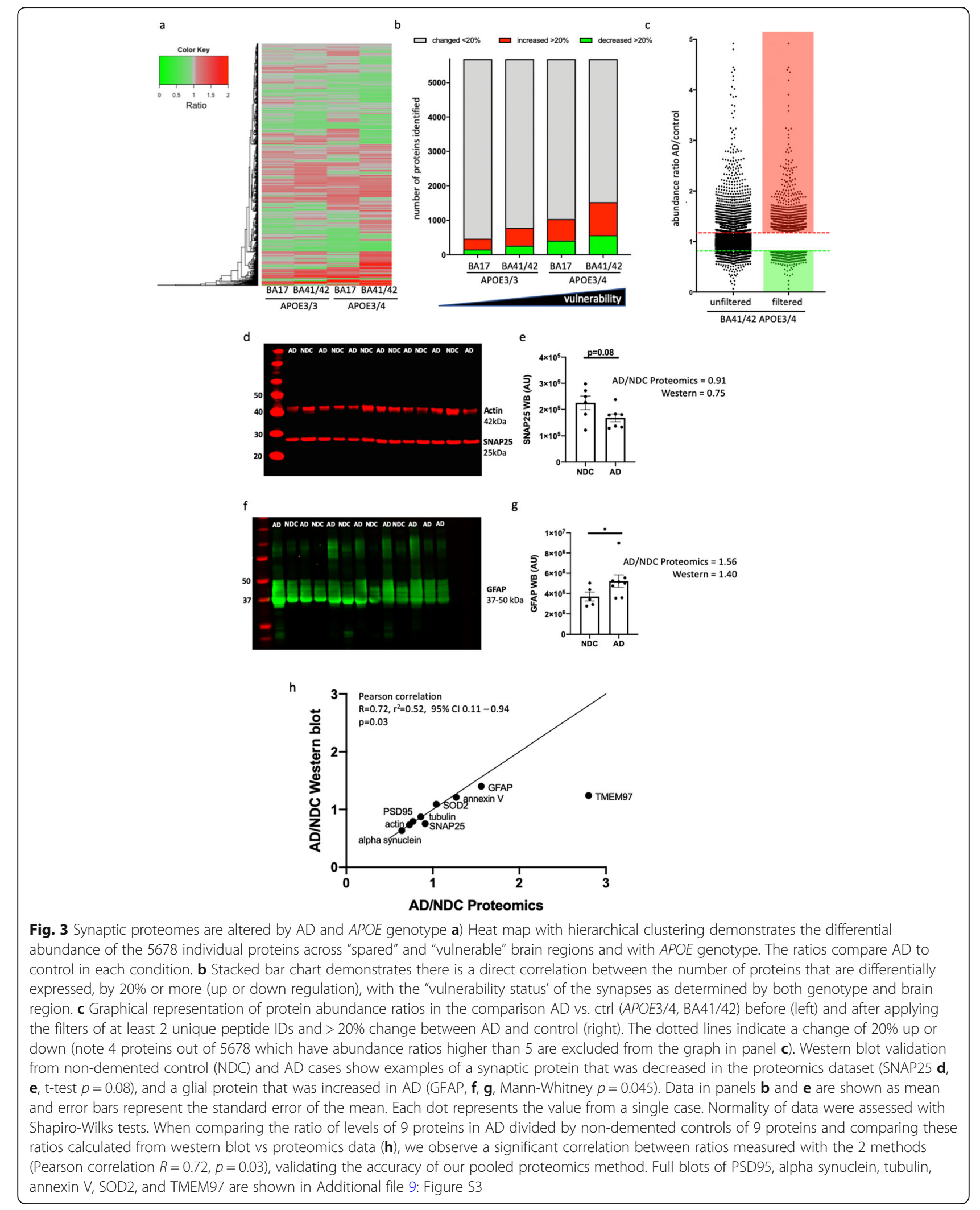




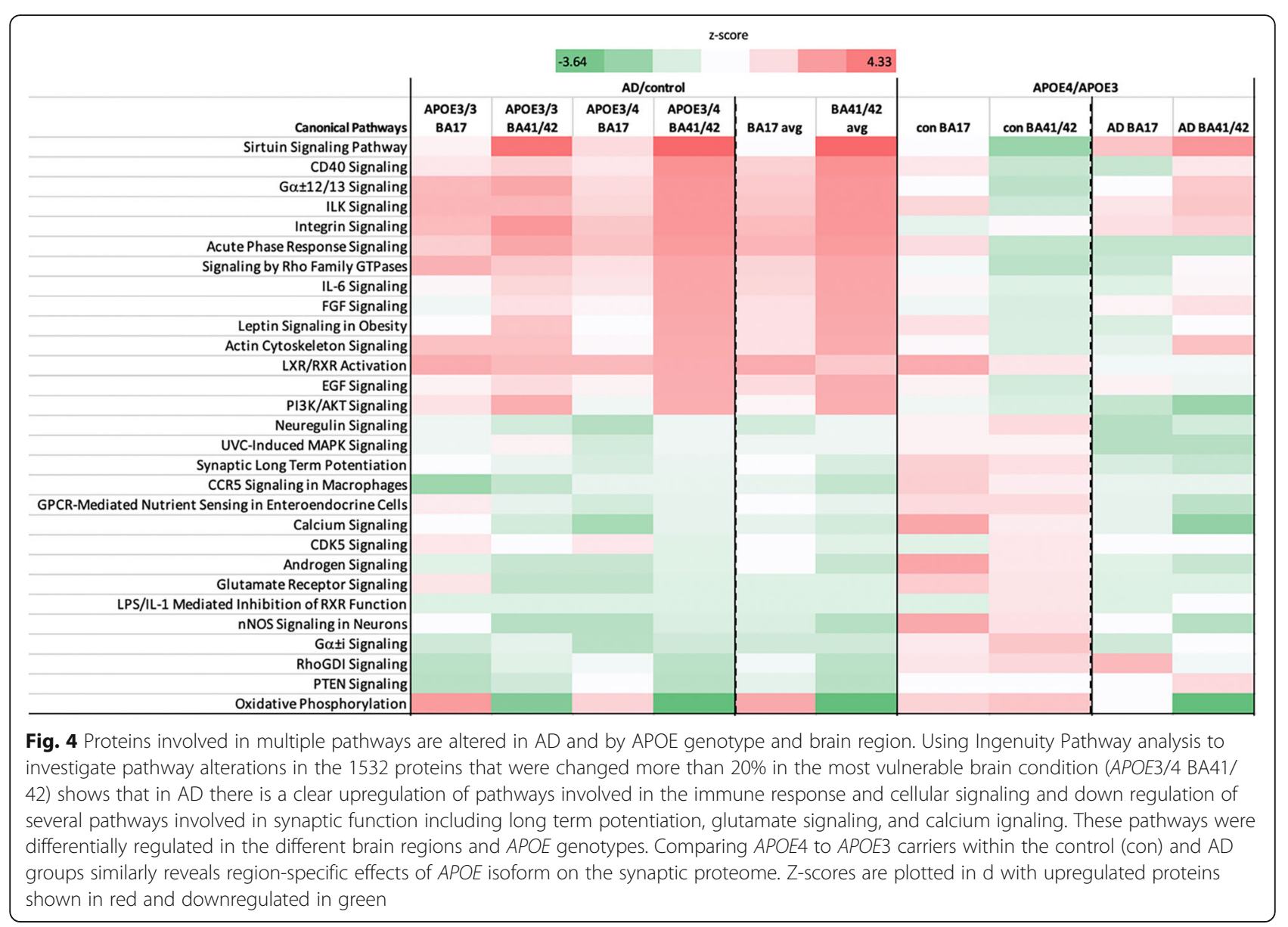

across the four calculated ratios (Fig. 5). Each sphere represents an individual protein ID and the distances between the spheres indicate the similarity in abundance profile. Different colours are used to group proteins together in clusters based on abundance profile similarity. In order to analyse the impact/influence of $A P O E$ genotype and cortical region, we focused specifically on clusters showing a steady increase or decrease in protein abundance across the four groups or only demonstrating differences in protein abundance in APOE4 carriers in BA41/42 (Fig. 5). In order to determine if these abundance profile specific clusters were associated with specific pathways and/or canonical cascades, we have carried out a higher order functional clustering analysis using IPA software. IPA pathway analysis and DAVID enrichment analysis highlighted multiple affected pathways. In clusters $4,5,8$ and 21 which have progressive decreases in $\mathrm{AD} /$ control ratios as pathological severity increases (Fig. 5), we observe pathways involved in synaptic function are decreased including glutamate signalling, synaptic long term potentiation, GABA receptor signalling, CREB signalling, and synaptic long-term depression. Cluster 6 containing proteins that were sharply decreased in the condition with most pathology, $A D$ APOE4 BA41/42, similarly showed decreases in pathways involved in synaptic function including CREB signalling and GABA receptor signalling, along with decreases in pathways implicated in mitochondrial function including oxidative phosphorylation (Fig. 5).

Interestingly, when examining clusters 7, 9, and 18 which were progressively increased with pathological vulnerability, we observe proteins involved in autophagy and chemokine signalling were progressively upregulated in conditions of higher synaptic vulnerability (Fig. 5). Clusters 1 and 2, which included proteins highly upregulated in $\mathrm{AD} A P O E 4$ BA41/42 compared to the other groups indicate increases in pathways involved in actin cytoskeleton signalling, NRF2 mediated oxidative stress response, PDGF signalling, and insulin receptor signalling, which all implicate non-neuronal contributors to synapse degeneration as has been recently emphasised for AD risk by genetic studies [18].

Along with the unbiased bioinformatic analyses, we further interrogated our proteomics dataset to examine proteins of interest based on what is known about synapse degeneration in $\mathrm{AD}$ from model systems. In 


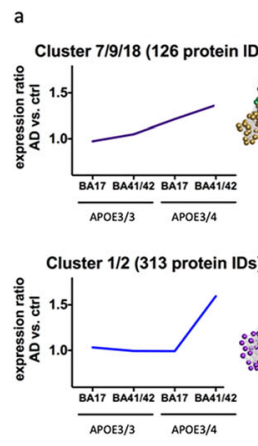

b
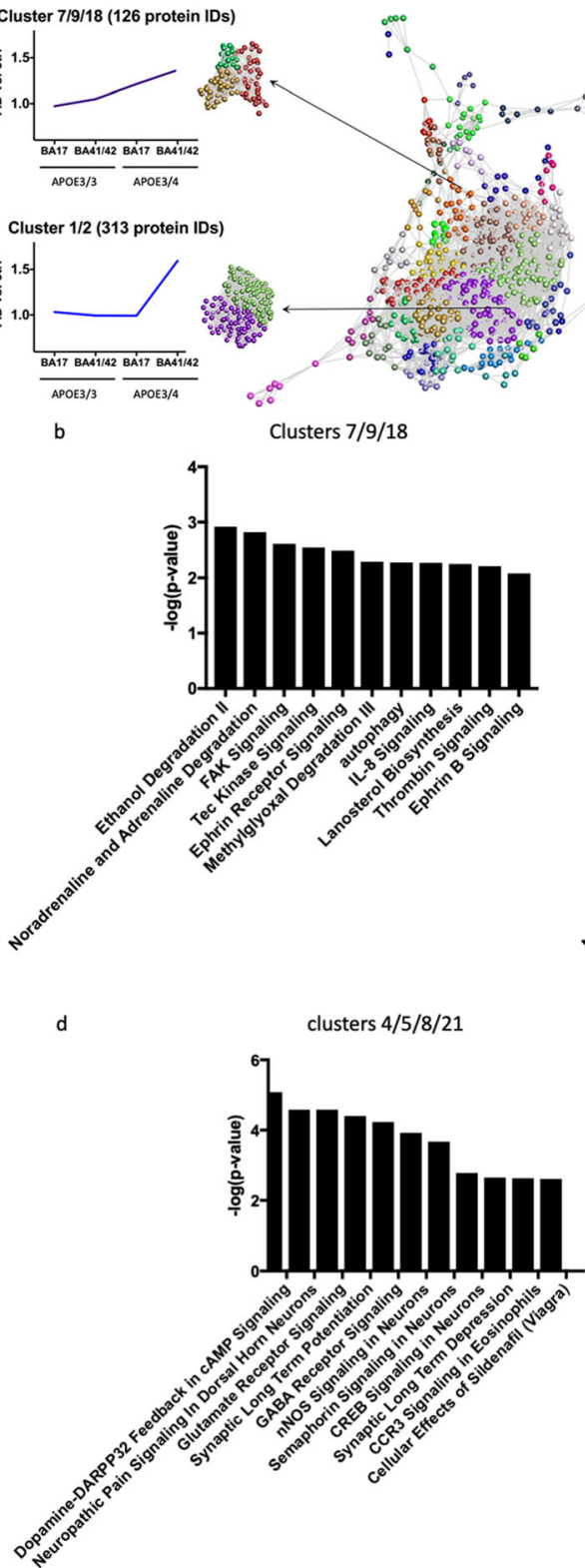

$\infty$ Clusters $7 / 9 / 18$
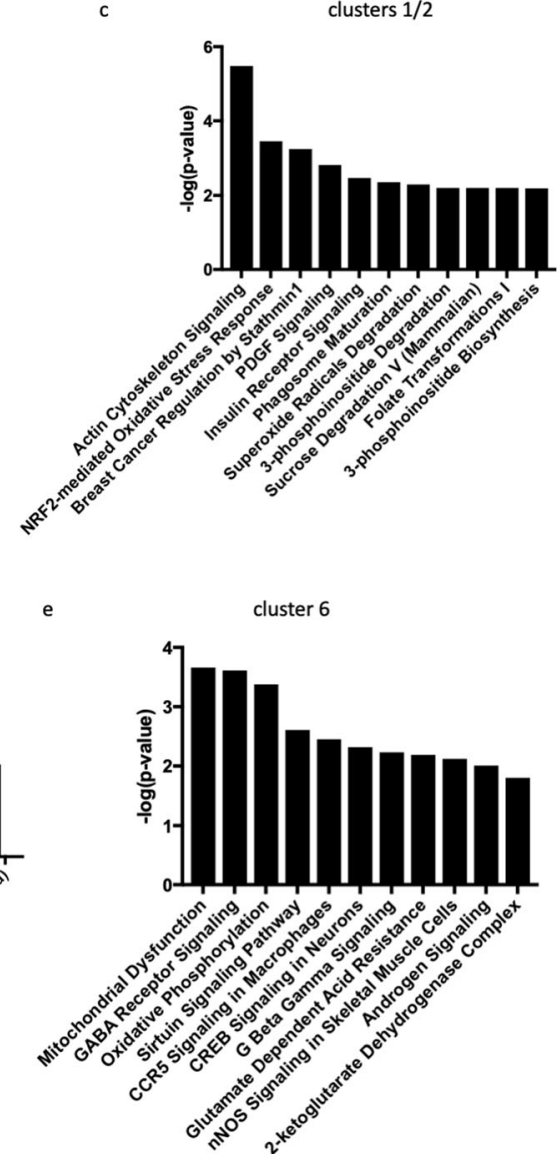

Fig. 5 Clusters of protein changes. a Graphia Professional representation of proteomic abundance data across differentially vulnerable synaptic populations. Each sphere represents a single protein and the edge represents how similar their abundance trend is towards the other proteins in the dataset. The closer the spheres are the more similar the abundance trend. The colours represent the different clusters formed by grouping proteins with similar abundance trends. The resulting profiles were grouped into four different categories as shown in the example graphical abundance trends for further analysis. The annotation associated with each graph represents the cluster numbers which fit each trend and the number of associated proteins. Graphs b-e show the top pathway changes in the clusters indicated

addition to loss of proteins involved in synaptic function in remaining synapses in AD as shown with bioinformatics, it is likely that there is some degree of synaptic remodelling/compensation taking place as some synaptic proteins were increased. The synaptic receptor TMEM97 is increased in remaining synapses in $\mathrm{AD}$ vs control APOE4 carriers in BA41/42 (Fig. 3). This is particularly interesting because TMEM97 is the sigma 2 receptor, and compounds that disrupt interaction of $A \beta$ and sigma 2 receptors are protective in mouse models and are being tested for efficacy in human $\mathrm{AD}$ as a therapeutic [23]. Clusterin is also increased $21 \%$ in AD compared to controls. This is interesting in light of our recent work showing clusterin within individual synapses containing amyloid beta in human $\mathrm{AD}$ brain using high resolution imaging [24]. 
Recent data strongly implicate the complement cascade and microglia in $\mathrm{A} \beta$ mediated synapse loss in mouse models of amyloid deposition [20, 46]. Two studies recently demonstrated upregulation of components of the complement system in $\mathrm{AD}$ brain and influence of complement cascade in synapse dysfunction and loss in a mouse model of tauopathy [12, 31]. Based on these data, we interrogated our human synaptoneurosome dataset to look at proteins important for microglial synapse phagocytosis and specifically the complement system. Pathway analysis reveals increases in CD40, IL-6, IL-8, IL-1, IL-2, IL-7 and acute phase response signalling, indicating neuroimmune signalling between neurons and glia in synapses, which is modulated by $A P O E$ genotype (Figs. 4 and 5). Further interrogation of the proteomics dataset shows increases in $\mathrm{C} 1 \mathrm{qA}, \mathrm{B}$, and $\mathrm{C}$ in $\mathrm{AD}$ brain, which are most pronounced in BA41/42 of APOE3 carriers (over 2 fold increases). We also detect complement components $\mathrm{C} 1$ and $\mathrm{C} 4$ which are increased in most conditions $\mathrm{AD}$ brain without a clear effect of $A P O E$ genotype (Additional file 4: Table S4).

\section{Discussion}

Of the pathological changes associated with dementia, the best correlate to the extent of memory decline in life is the loss of synapses. Synapses are exquisitely complicated structures requiring thousands of proteins for the complex process of establishing, maintaining, and undergoing synaptic transmission. Work from animal models and human post mortem tissue indicates that synapse degeneration is a driving force in disease progression in AD. However, to date there has been a lack of data on the precise molecular changes in synapses in human AD brain, which impedes the design of hypothesis driven experiments to understand mechanisms of synapse degeneration in animal models that are likely to be relevant to human disease. In the literature, we found 20 publications using proteomics on human $\mathrm{AD}$ brain tissue (Additional file 1: Table S1). In proteomics studies examining whole tissue homogenates from AD brains without considering $A P O E$ genotype, there have been quite varied results. Three studies show decreases in synaptic proteins or pathways involved in synaptic function, which could have been explained by synapse loss $[1,38$, 59]. To our knowledge only one previous study examined the effects of $A P O E$ on synaptic proteins [53]. This study used whole tissue homogenates from $\mathrm{AD}$ and control subjects for proteomics but focused their analysis on a group of 191 proteins that had previously been detected in synaptosome fractions of healthy subjects. With this method, they observed a downregulation of glutamate signalling proteins and an effect of $A P O E 4$ genotype on the abundance of these synaptic proteins. Our results significantly expand upon these findings as we biochemically isolated synaptoneurosomes from $\mathrm{AD}$ and control subjects and detected over 5500 proteins, which is over 25 times more proteins examined than in the previous study of synaptic proteins. Synaptoneurosome preparations have not previously been used in proteomic studies of AD. Synaptoneurosomes, unlike other synaptic fractions, contain both the presynaptic and postsynaptic compartments, which is important due to data from model systems implicating both pre and post synapses in degenerative mechanisms. Further, the preparation might retain parts of glial processes closely associated with the synapse, which is key for understanding the role of non-neuronal cells in synapse degeneration, an important topic in the field [18].

We observed that multiple pathways including those associated with synaptic and mitochondrial function were downregulated with increasing vulnerability and other pathways including intracellular signalling and neuroimmune signalling proteins were increased with increasing vulnerability. This is encouraging as dysfunctional synaptic signalling is consistent with multiple lines of evidence from AD animal models [5, 43, 48]. Some of the proteins that we observe are reduced in $\mathrm{AD}$ synapses have been observed as CSF biomarkers associating with disease. For example, we observe a $25 \%$ decrease in neurexin 2 and over $30 \%$ decrease in neurogranin abundance in $\mathrm{AD} A P O E 4$ superior temporal gyrus compared to controls, whereas recently published biomarker studies observed increases in neurexin 2 and neurogranin in CSF of people with mild cognitive impairment or $\mathrm{AD}$ $[14,29,41]$. In another study of CSF, a group of 9 synaptic proteins (GluR2, GluR4, Neuroligin-2, Neurexin-3A, Neurexin-2A, Calsynytenin-1, Syntaxin-1B, Thy-1, and VAMP-2) were increased [33]. Our proteomics data support the notion that proteins may be removed from synapses in $\mathrm{AD}$ and at least some of these cleared from the brain via CSF.

In addition to the synaptic signalling pathway changes, we observe interesting changes in immunerelated signals in $\mathrm{AD}$ synapses. In recent work examining both iPSCs and human brain tissue, APOE4 was strongly associated with reduced expression of regulators of synaptic function and increased expression of microglial genes associated with the immune response [57]. $A P O E$ has been shown to interact with and modulate the immune and inflammatory system in the brain especially through its interaction with another important AD genetic risk factor TREM2 [4]. Our study also found that proteins involved in the immune system and neuroimmune signalling are dysregulated in the $\mathrm{AD}$ synapse. Recent evidence has indicated that the complement system of innate immunity, particularly complement components $\mathrm{C} 1 \mathrm{q}$ and $\mathrm{C} 3$, are involved 
in synaptic death in mouse models both downstream of $\mathrm{A} \beta$ and tau pathology, and that ApoE forms a complex with activated $\mathrm{C} 1 \mathrm{q}$ which blocks initiation of the complement cascade [12, 20, 31, 46, 58]. Our study highlights the importance of these pathways in human $\mathrm{AD}$ brain and shows that other proteins in this cascade including complement component C4, HLA-1, and Clusterin are all increased at the synapse in $\mathrm{AD}$ presenting innate immunity as an attractive area for further study and therapeutic intervention. Our data indicate that within remaining synapses in human $\mathrm{AD}$ brain, APOE4 is associated with altered levels of proteins involved in synaptic function and proteins involved in the innate immune system. One possible interpretation of these data supports the hypothesis that microglia are involved in synaptic pruning during disease.

Synapses have high energy demands requiring local mitochondrial ATP production. Both $\mathrm{A} \beta$ and tau have been observed in model systems to impact mitochondrial function and the intracellular transport of mitochondria, which impair synaptic function [30, 34, 42]. And there is some evidence that APOE4 can impair mitochondria function in cell culture [8]. However, the role of APOE4 in synaptic mitochondrial function in human brain has not been studied. We observe region and $A P O E$ specific changes in proteins involved oxidative phosphorylation with a strong decrease in BA41/42 of $\mathrm{AD}$ patients that was larger in $A P O E 4$ carriers than $A P O E 3$ carriers. Conversely, this pathway was increased in BA17 with the strongest increase in E3 carriers. This could reflect a compensatory increase in mitochondrial function in brain regions that are very early in the disease process. Consistent with the BA41/42 data, we recently observed a decrease in presynaptic terminals containing multiple mitochondria in the temporal cortex of $\mathrm{AD}$ patients [40].

Synaptic degeneration is an important part of $A D$ pathogenesis. Further understanding this process and how to delay and/or halt it may lead us towards important novel therapeutic targets not only for AD but also for other diseases for which synapse loss is an integral or important process. As indicated in Fig. 1a and as expected from the literature, APOE4 $\mathrm{AD}$ cases have a higher degree of amyloid pathology than $A P O E 3 \mathrm{AD}$ cases. Our data cannot disentangle whether APOE4 directly affects the synaptic proteome or does so downstream of increasing pathology. We argue that understanding the differences in synaptic proteome in $A D$ vs control and APOE4 vs APOE3 will be an important starting point for future mechanistic experiments looking for therapeutic interventions. By coupling subcellular fractionation with anatomical knowledge of regional vulnerability and human patient genetics we were able to generate the most comprehensive synaptic proteomics profiling datasets from human $\mathrm{AD}$ patient samples to date. Importantly, we have determined its accuracy through experimental validation and links to existing published literature on mechanisms and biomarker identification. As an example of the potential utility of such data we were able to begin to uncover how $\mathrm{AD}$ and APOE4 impact synaptic composition and may be leading to synaptic degeneration. Although in this discussion we have highlighted specific proteins and cascades correlating with regional vulnerability and discussed their potential roles in disease progression and /or regulation this was done to highlight the potential utility of our dataset. There are many other potentially important proteins and pathways in these data to explore in future studies. We have made the data freely available and hope that this will provide a useful resource for other researchers in the field to use at their discretion. The results described here demonstrate that $A P O E$ genotype has a profound impact on the molecular fingerprint of the synapse and that further understanding of the effects of these protein changes may contribute to our understanding of, and ultimately the development of novel therapies for AD.

\section{Supplementary information}

Supplementary information accompanies this paper at https://doi.org/10. 1186/s40478-019-0847-7.

Additional file 1: Table S1. Systematic literature search for $A D$ proteomics studies.

Additional file 2: Table S2. DAVID Analysis confirms enrichment of synaptic proteins.

Additional file 3: Table S3. IPA analysis output.

Additional file 4: Table S4. Evidence for alterations in proteins involved in the complement cascade in human AD synapses.

Additional file 5: Table S5. Proteomics raw data.

Additional file 6: Table S6. Filtered proteomics data used for IPA analysis in Fig. 3.

Additional file 7: Figure S1. Proteomics workflow. Samples were prepared from postmortem tissue and processed for proteomics analysis according to the workflow shown.

Additional file 8: Figure S2. Protein degradation blot example. Protein degradation blots were completed for all samples using NMDA NR2B antibody (a). The ratio of band 1, which is found in vivo, to band 2, which appears with postmoretem degradation was calculated (b) and samples with a ratio $<1$ were excluded from the study.

Additional file 9: Figure S3. Validation western blots. Validation western blots (uncropped) of AD vs non demented control (NDC) from BA41/42 of people with APOE3/4 genotype. Full blots are shown for PSD95 and alpha-synuclein (a), SOD2 (b), annexin V (c), TMEM97 (d), beta tubulin (e), and total protein at high intensity ( $f$ ) and low intensity (g). Each of the molecular weight ranges in $g$ were quantified for each lane, shown in (h). Comparisons between proteomics and western blot data are shown in i.

\section{Acknowledgements}

The authors thank our brain tissue donors and their families for their generous donations and Amy Tavendale for her help LC-MS/MS data acquisition. Authors gratefully acknowledge membership of Edinburgh Neuroscience. Some of the control participants in the human study were from the Lothian Birth Cohort 1936, thus we wish to thank the cohort and research 
team supported by Age UK (Disconnected Mind project) in The University of Edinburgh Centre for Cognitive Ageing and Cognitive Epidemiology, funded by the Biotechnology and Biological Sciences Research Council (BBSRC) and Medical Research Council (MRC) ((MR/K026992/1). We thank Prof Marian DiFigia and the Philly Dake Electron Microscopy Centre at Massachusetts General Hospital for the use of the TEM.

\section{Authors' contributions}

Study concept and design: TSJ, TMW, AGH, RH, RJj; acquisition of data: RH, RJJ, SLE, MT, MCC, JR, JT, C-AM, CS, CH, DL; analysis and interpretation of data: RH, MLH, DK, TMW, TSJ; drafting of the manuscript: RH, TSJ, TMW; critical revision of the manuscript for important intellectual content: TSJ, TMW, SLE, MLE. All authors read and approved the final manuscript.

\section{Funding}

This work was supported by Alzheimer's Society (project grant AS-PG-15b-023), Alzheimer's Research UK, the European Research Council (ERC) under the European Union's Horizon 2020 research and innovation programme (Grant agreement No. 681181), the University of Edinburgh (Chancellor's Fellow startup funding), Wellcome Trust Institutional Strategic Support Fund, the UK Dementia Research Institute which receives its funding from DRI Ltd., funded by the UK Medical Research Council, Alzheimer's Society, and Alzheimer's Research UK, and BBSRC Institute Strategic Programme funding.

\section{Ethics approval and consent to participate}

Use of human tissue for post-mortem studies has been reviewed and approved by the Edinburgh Brain Bank ethics committee and the ACCORD medical research ethics committee, AMREC (ACCORD is the Academic and Clinical Central Office for Research and Development, a joint office of the University of Edinburgh and NHS Lothian - Ethics approval reference 15HV-016). The Edinburgh Brain Bank is a Medical Research Council funded facility with research ethics committee (REC) approval (16/ES/0084). Tissue from 33 donors was used for this study and their details are found in Table 1.

\section{Competing interests}

TSJ is a member of the scientific Advisory Board of Cognition Therapeutics. The company had no influence over the experiments reported in this paper.

\section{Author details}

${ }^{1}$ Centre for Discovery Brain Sciences, UK Dementia Research Institute, The University of Edinburgh, 1 George Square, Edinburgh EH8 9JZ, Scotland, UK. ${ }^{2}$ College of Medicine and Veterinary Medicine, The Roslin Institute and Royal (Dick) School of Veterinary Studies, University of Edinburgh, Easter Bush, Midlothian EH25 9RG, Scotland, UK. ${ }^{3}$ Centre for Clinical Brain Sciences, University of Edinburgh, Edinburgh, Scotland, UK. ${ }^{4}$ Division of Systems Medicine, Neuroscience, Ninewells Hospital \& Medical School, University of Dundee, Dundee, UK. ${ }^{5}$ FingerPrints Proteomics Facility, College of Life Sciences, University of Dundee, Dundee, Scotland, UK.

\section{Received: 11 November 2019 Accepted: 13 November 2019} Published online: 20 December 2019

\section{References}

1. Andreev VP, Petyuk VA, Brewer HM, Karpievitch W, Xie F, Clarke J, Camp D, Smith RD, Lieberman AP, Albin RL et al (2012) Label-free quantitative LC-MS proteomics of Alzheimer's disease and normally aged human brains. J Proteome Res 11:30533067. https:/doi.org/10.1021/pr3001546

2. Arboleda-Velasquez JF, Lopera F, O'Hare M, Delgado-Tirado S, Marino C, Chmielewska N, Saez-Torres KL, Amarnani D, Schultz AP, Sperling RA et al (2019) Resistance to autosomal dominant Alzheimer's disease in an APOE3 Christchurch homozygote: a case report. Nature Medicine: Doi. https://doi.org/10.1038/s41591-019-0611-3

3. Arold S, Sullivan P, Bilousova T, Teng E, Miller CA, Poon WW, Vinters HV, Cornwell LB, Saing T, GM C et al (2012) Apolipoprotein E level and cholesterol are associated with reduced synaptic amyloid beta in Alzheimer's disease and apoE TR mouse cortex. Acta Neuropathol 123:3952. https://doi.org/10.1007/s00401-011-0892-1

4. Atagi Y, Liu CC, Painter MM, Chen XF, Verbeeck C, Zheng H, Li X, Rademakers R, Kang SS, Xu Het al (2015) Apolipoprotein E is a ligand for triggering receptor expressed on myeloid cells 2 (TREM2). J Biol Chem 290: 26043-26050 Doi https://doi.org/10.1074/jbc.M115.679043
5. Baglietto-Vargas D, Prieto GA, Limon A, Forner S, Rodriguez-Ortiz CJ, Ikemura K, Ager RR, Medeiros R, Trujillo-Estrada L, Martini AC et al (2018) Impaired AMPA signaling and cytoskeletal alterations induce early synaptic dysfunction in a mouse model of Alzheimer's disease Aging Cell:e12791. https://doi.org/10.1111/acel.12791

6. Bayes A, Collins MO, Galtrey CM, Simonnet C, Roy M, Croning MD, Gou G, van de Lagemaat LN, Milward D, Whittle IR et al (2014) Human postmortem synapse proteome integrity screening for proteomic studies of postsynaptic complexes. Mol Brain 7:88. https://doi.org/10.1186/s13041014-0088-4

7. Carlyle BC, Kitchen RR, Kanyo JE, Voss EZ, Pletikos M, Sousa AMM, Lam TT, Gerstein MB, Sestan N, Nairn AC (2017) A multiregional proteomic survey of the postnatal human brain. Nat Neurosci 20:1787-1795. https://doi.org/10. 1038/s41593-017-0011-2

8. Chang S, ran Ma T, Miranda RD, Balestra ME, Mahley RW, Huang Y (2005) Lipid- and receptor-binding regions of apolipoprotein E4 fragments act in concert to cause mitochondrial dysfunction and neurotoxicity. Proc Natl Acad Sci U S A 102:18694-18699. https://doi.org/10.1073/pnas.0508254102

9. Corder EH, Saunders AM, Strittmatter WJ, Schmechel DE, Gaskell PC, Small GW, Roses AD, Haines JL, Pericak-Vance MA (1993) Gene dose of apolipoprotein E type 4 allele and the risk of Alzheimer's disease in late onset families. Science 261:921-923

10. Cox J, Mann M (2008) MaxQuant enables high peptide identification rates, individualized p.p.b.-range mass accuracies and proteome-wide protein quantification. Nat Biotechnol 26:1367-1372. https://doi.org/10. 1038/nbt.1511

11. Cox J, Neuhauser N, Michalski A, Scheltema RA, Olsen JV, Mann M (2011) Andromeda: a peptide search engine integrated into the MaxQuant environment. J Proteome Res 10:1794-1805. https://doi.org/10.1021/pr101065j

12. Dejanovic B, Huntley MA, De Maziere A, Meilandt WJ, Wu T, Srinivasan K, Jiang Z, Gandham V, Friedman BA, Ngu Het al (2018) Changes in the synaptic proteome in Tauopathy and Rescue of tau-Induced Synapse Loss by C1q antibodies. Neuron: Doi https://doi.org/10.1016/j.neuron. 2018.10.014

13. DeKosky ST, Scheff SW, Styren SD (1996) Structural correlates of cognition in dementia: quantification and assessment of synapse change. Neurodegeneration 5:417-421

14. Duits FH, Brinkmalm G, Teunissen CE, Brinkmalm A, Scheltens P, Van der Flier WM, Zetterberg H, Blennow K (2018) Synaptic proteins in CSF as potential novel biomarkers for prognosis in prodromal Alzheimer's disease. Alzheimers Res Ther 10:5. https://doi.org/10.1186/s13195-017-0335-x

15. Graham LC, Eaton SL, Brunton PJ, Atrih A, Smith C, Lamont DJ, Gillingwater TH, Pennetta G, Skehel P, Wishart TM (2017) Proteomic profiling of neuronal mitochondria reveals modulators of synaptic architecture. Mol Neurodegener 12:77. https://doi.org/10.1186/s13024-017-0221-9

16. Graham LC, Naldrett MJ, Kohama SG, Smith C, Lamont DJ, McColl BW Gillingwater TH, Skehel P, Urbanski HF, Wishart TM (2019) Regional molecular mapping of primate synapses during normal healthy ageing. Cell Rep 27 (1018-1026):e1014. https://doi.org/10.1016/j.celrep.2019.03. 096

17. Henstridge CM, Sideris DI, Carroll E, Rotariu S, Salomonsson S, Tzioras M, McKenzie CA, Smith C, von Arnim CAF, Ludolph ACet al (2018) Synapse loss in the prefrontal cortex is associated with cognitive decline in amyotrophic lateral sclerosis. Acta Neuropathol 135: 213-226 Doi https://doi.org/10.1007/ s00401-017-1797-4

18. Henstridge CM, Spires-Jones T (2019) Beyond the neuron - cellular interactions early in Alzheimer's disease pathogenesis. Nat Rev Neurosci

19. Hesse R, von Einem B, Wagner F, Bott P, Schwanzar D, Jackson RJ, Föhr KJ, Lausser L, Kroker KS, Proepper C et al (2018) SAPP 3 and SAPPa increase structural complexity and $\mathrm{E} / \mathrm{I}$ input ratio in primary hippocampal neurons and alter Ca. Exp Neurol 304:1-13. https://doi.org/10.1016/j.expneurol.2018. 02.010

20. Hong S, Beja-Glasser VF, Nfonoyim BM, Frouin A, Li S, Ramakrishnan S, Merry KM, Shi Q, Rosenthal A, Barres BA et al (2016) Complement and microglia mediate early synapse loss in Alzheimer mouse models. Science: Doi. https://doi.org/10.1126/science.aad8373

21. Huang DW, Sherman BT, Lempicki RA (2009) Systematic and integrative analysis of large gene lists using DAVID bioinformatics resources. Nat Protoc 4:44-57. https://doi.org/10.1038/nprot.2008.211

22. Hudry E, Dashkoff J, Roe AD, Takeda S, Koffie RM, Hashimoto T, Scheel M, Spires-Jones T, Arbel-Ornath M, Betensky R et al (2013) Gene transfer of 
human Apoe isoforms results in differential modulation of amyloid deposition and neurotoxicity in mouse brain. Sci Transl Med 5:212ra161. https://doi.org/10.1126/scitransImed.3007000

23. Izzo NJ, Xu J, Zeng C, Kirk MJ, Mozzoni K, Silky C, Rehak C, Yurko R, Look G, Rishton Get al (2014) Alzheimer's therapeutics targeting amyloid beta 1-42 oligomers II: Sigma-2/PGRMC1 receptors mediate Abeta 42 oligomer binding and synaptotoxicity. PLoS One 9: e111899 Doi https://doi.org/10. 1371/journal.pone.0111899

24. Jackson RJ, Rose J, Tulloch J, Henstridge C, Smith C, Spires-Jones TL (2019) Clusterin accumulates in synapses in Alzheimer's disease and is increased in apolipoprotein E4 carriers. Brain Commun 1. https://doi.org/10.1093/ braincomms/fcz003

25. Jones RA, Harrison C, Eaton SL, Llavero Hurtado M, Graham LC, Alkhammash L, Oladiran OA, Gale A, Lamont DJ, Simpson H et al (2017) Cellular and molecular anatomy of the human neuromuscular junction. Cell Rep 21: 2348-2356. https://doi.org/10.1016/j.celrep.2017.11.008

26. Kay KR, Smith C, Wright AK, Serrano-Pozo A, Pooler AM, Koffie R, Bastin ME, Bak TH, Abrahams S, Kopeikina KJ et al (2013) Studying synapses in human brain with array tomography and electron microscopy. Nat Protoc 8:13661380. https://doi.org/10.1038/nprot.2013.078

27. Koffie RM, Hashimoto T, Tai HC, Kay KR, Serrano-Pozo A, Joyner D, Hou S, Kopeikina KJ, Frosch MP, Lee VM et al (2012) Apolipoprotein E4 effects in Alzheimer's disease are mediated by synaptotoxic oligomeric amyloid-beta. Brain 135:2155-2168. https://doi.org/10.1093/brain/aws127

28. Krasemann S, Madore C, Cialic R, Baufeld C, Calcagno N, El Fatimy R, Beckers L, O'Loughlin E, Xu Y, Fanek Zet al (2017) The TREM2-APOE pathway drives the transcriptional phenotype of dysfunctional microglia in neurodegenerative diseases. Immunity 47: 566-581 e569 Doi https://doi. org/10.1016/j.immuni.2017.08.008

29. Kvartsberg $H$, Duits FH, Ingelsson M, Andreasen N, Ohrfelt A, Andersson K, Brinkmalm G, Lannfelt L, Minthon L, Hansson $O$ et al (2015) Cerebrospinal fluid levels of the synaptic protein neurogranin correlates with cognitive decline in prodromal Alzheimer's disease. Alzheimers Dement 11:1180-1190. https://doi.org/10.1016/j.jalz.2014.10.009

30. Lasagna-Reeves CA, Castillo-Carranza DL, Sengupta U, Clos AL, Jackson GR, Kayed R (2011) Tau oligomers impair memory and induce synaptic and mitochondrial dysfunction in wild-type mice. Mol Neurodegener 6:39. https://doi.org/10.1186/1750-1326-6-39

31. Litvinchuk A, Wan YW, Swartzlander DB, Chen F, Cole A, Propson NE, Wang Q, Zhang B, Liu Z, Zheng H (2018) Complement C3aR inactivation attenuates tau pathology and reverses an immune network deregulated in Tauopathy models and Alzheimer's disease. Neuron: Doi. https://doi.org/10. 1016/j.neuron.2018.10.031

32. Llavero Hurtado M, Fuller HR, Wong AMS, Eaton SL, Gillingwater TH, Pennetta G, Cooper JD, Wishart TM (2017) Proteomic mapping of differentially vulnerable pre-synaptic populations identifies regulators of neuronal stability in vivo. Sci Rep 7:12412. https://doi.org/10.1038/s41598017-12603-0

33. Lleó A, Núñez-Llaves R, Alcolea D, Chiva C, Balateu-Paños D, ColomCadena M, Gomez-Giro G, Muñoz L, Querol-Vilaseca M, Pegueroles Jet al (2019) Changes in synaptic proteins precede Neurodegeneration markers in preclinical Alzheimer's disease cerebrospinal fluid. Molecular \&amp; Cellular Proteomics 18: 546-560 Doi https://doi.org/10.1074/mcp.RA118.001290

34. Manczak M, Kandimalla R, Fry D, Sesaki H, Reddy PH (2016) Protective effects of reduced dynamin-related protein 1 against amyloid betainduced mitochondrial dysfunction and synaptic damage in Alzheimer's disease. Hum Mol Genet 25:5148-5166. https://doi.org/10.1093/hmg/ ddw330

35. Mauricio R, Benn C, Davis J, Dawson G, Dawson LA, Evans A, Fox N, Gallacher J, Hutton M, Isaac Jet al (2019) Tackling gaps in developing lifechanging treatments for dementia. Alzheimers Dement (N Y) 5: 241-253 Doi https://doi.org/10.1016/j.trci.2019.05.001

36. McGorum BC, Pirie RS, Eaton SL, Keen JA, Cumyn EM, Arnott DM, Chen W, Lamont DJ, Graham LC, Llavero Hurtado Met al (2015) Proteomic profiling of cranial (superior) cervical ganglia reveals Beta-amyloid and ubiquitin proteasome system perturbations in an equine multiple system neuropathy. Mol Cell Proteomics 14: 3072-3086 Doi https://doi.org/10.1074/mcp.M115. 054635

37. Molinari N, Roche S, Peoc'h K, Tiers L, Seveno M, Hirtz C, Lehmann S (2018) Sample pooling and inflammation linked to the false selection of biomarkers for neurodegenerative diseases in top-down proteomics: a pilot study. Front Mol Neurosci 11:477. https://doi.org/10.3389/fnmol.2018.00477

38. Musunuri $\mathrm{S}$, Wetterhall $M$, Ingelsson $M$, Lannfelt $L$, Artemenko $K$, Bergquist J, Kultima K, Shevchenko G (2014) Quantification of the brain proteome in Alzheimer's disease using multiplexed mass spectrometry. J Proteome Res 13:2056-2068. https://doi.org/10.1021/pr401202d

39. Perez-Riverol Y, Csordas A, Bai J, Bernal-Llinares M, Hewapathirana S, Kundu DJ, Inuganti A, Griss J, Mayer G, Eisenacher M et al (2019) The PRIDE database and related tools and resources in 2019: improving support for quantification data. Nucleic Acids Res 47:D442-D450. https://doi.org/10. 1093/nar/gky1106

40. Pickett EK, Rose J, McCrory C, McKenzie CA, King D, Smith C, Gillingwater TH, Henstridge CM, Spires-Jones TL (2018) Region-specific depletion of synaptic mitochondria in the brains of patients with Alzheimer's disease. Acta Neuropathol 136:747-757. https://doi.org/10.1007/s00401-018-1903-2

41. Portelius E, Olsson B, Hoglund K, Cullen NC, Kvartsberg H, Andreasson U, Zetterberg H, Sandelius A, Shaw LM, VMY L et al (2018) Cerebrospinal fluid neurogranin concentration in neurodegeneration: relation to clinical phenotypes and neuropathology. Acta Neuropathol 136:363-376. https://doi.org/10.1007/s00401-018-1851-x

42. Reddy PH, Beal MF (2008) Amyloid beta, mitochondrial dysfunction and synaptic damage: implications for cognitive decline in aging and Alzheimer's disease. Trends Mol Med 14:45-53. https://doi.org/10.1016/j. molmed.2007.12.002

43. Reinders NR, Pao Y, Renner MC, da Silva-Matos CM, Lodder TR, Malinow R, Kessels HW (2016) Amyloid-beta effects on synapses and memory require AMPA receptor subunit GluA3. Proc Natl Acad Sci U S A 113:E6526-E6534. https://doi.org/10.1073/pnas.1614249113

44. Riad A, Zeng C, Weng CC, Winters H, Xu K, Makvandi M, Metz T, Carlin S, Mach RH (2018) Sigma-2 receptor/TMEM97 and PGRMC-1 increase the rate of internalization of LDL by LDL receptor through the formation of a ternary complex. Sci Rep 8:16845. https://doi.org/10.1038/541598-018-35430-3

45. Serrano-Pozo A, Frosch MP, Masliah E, Hyman BT (2011) Neuropathological alterations in Alzheimer disease. Cold Spring Harb Perspect Med 1. https://doi.org/10.1101/cshperspect.a006189

46. Shi Q, Chowdhury S, Ma R, Le KX, Hong S, Caldarone BJ, Stevens B, Lemere CA (2017) Complement C3 deficiency protects against neurodegeneration in aged plaque-rich APP/PS1 mice. Sci Transl Med 9. https://doi.org/10.1126/ scitranslmed.aaf6295

47. Shi Y, Yamada K, Liddelow SA, Smith ST, Zhao L, Luo W, Tsai RM, Spina S, Grinberg LT, Rojas JC et al (2017) ApoE4 markedly exacerbates tau-mediated neurodegeneration in a mouse model of tauopathy. Nature 549:523-527. https://doi.org/10.1038/nature24016

48. Spires-Jones TL, Hyman BT (2014) The intersection of amyloid beta and tau at synapses in Alzheimer's disease. Neuron 82:756-771. https://doi.org/10. 1016/j.neuron.2014.05.004

49. Tai HC, Serrano-Pozo A, Hashimoto T, Frosch MP, Spires-Jones TL, Hyman BT (2012) The synaptic accumulation of hyperphosphorylated tau oligomers in Alzheimer disease is associated with dysfunction of the ubiquitinproteasome system. Am J Pathol 181:1426-1435. https://doi.org/10.1016/j. ajpath.2012.06.033

50. Tai LM, Bilousova T, Jungbauer L, Roeske SK, Youmans KL, Yu C, Poon WW, Cornwell LB, Miller CA, Vinters HV et al (2013) Levels of soluble apolipoprotein E/amyloid-beta (Abeta) complex are reduced and oligomeric Abeta increased with APOE4 and Alzheimer disease in a transgenic mouse model and human samples. J Biol Chem 288:5914-5926. https://doi.org/10. 1074/jbc.M112.442103

51. Terry RD, Masliah E, Salmon DP, Butters N, DeTeresa R, Hill R, Hansen $L A$, Katzman R (1991) Physical basis of cognitive alterations in Alzheimer's disease: synapse loss is the major correlate of cognitive impairment. Ann Neurol 30:572-580

52. Tzioras M, Davies C, Newman A, Jackson R, Spires-Jones T (2019) Invited review: APOE at the interface of inflammation, neurodegeneration and pathological protein spread in Alzheimer's disease. Neuropathol Appl Neurobiol 45:327-346. https://doi.org/10.1111/nan.12529

53. Wang S, Yang F, Petyuk VA, Shukla AK, Monroe ME, Gritsenko MA, Rodland KD, Smith RD, Qian WJ, Gong CX et al (2017) Quantitative proteomics identifies altered O-GlcNAcylation of structural, synaptic and memoryassociated proteins in Alzheimer's disease. J Pathol 243:78-88. https://doi. org/10.1002/path.4929

54. WHO (2017) Dementia, a global health priority. World Health Organisation, City 
55. Wishart TM, Paterson JM, Short DM, Meredith S, Robertson KA, Sutherland C, Cousin MA, Dutia MB, Gillingwater TH (2007) Differential proteomics analysis of synaptic proteins identifies potential cellular targets and protein mediators of synaptic neuroprotection conferred by the slow Wallerian degeneration (Wlds) gene. Mol Cell Proteomics 6: 1318-1330. https://doi.org/10.1074/mcp.M600457-MCP200

56. Wisniewski JR, Zougman A, Nagaraj N, Mann M (2009) Universal sample preparation method for proteome analysis. Nat Methods 6:359-362. https://doi.org/10.1038/nmeth.1322

57. Wu H-Y, Kuo P-C, Wang Y-T, Lin H-T, Roe AD, Wang BY, Han C-L, Hyman BT, Chen Y-J, Tai H-C (2018) $\beta$-Amyloid induces pathology-related patterns of tau hyperphosphorylation at synaptic terminals. J Neuropathol Exp Neurol 77:814-826. https://doi.org/10.1093/jnen/nly059

58. Yin C, Ackermann S, Ma Z, Mohanta SK, Zhang C, Li Y, Nietzsche S, Westermann M, Peng L. Hu Det al (2019) ApoE attenuates unresolvable inflammation by complex formation with activated C1q. Nat Med: Doi https://doi.org/10.1038/s41591-018-0336-8

59. Zhang Q, Ma C, Gearing M, Wang PG, Chin LS, Li L (2018) Integrated proteomics and network analysis identifies protein hubs and network alterations in Alzheimer's disease. Acta Neuropathol Commun 6:19. https://doi.org/10.1186/s40478-018-0524-2

\section{Publisher's Note}

Springer Nature remains neutral with regard to jurisdictional claims in published maps and institutional affiliations.

Ready to submit your research? Choose BMC and benefit from:

- fast, convenient online submission

- thorough peer review by experienced researchers in your field

- rapid publication on acceptance

- support for research data, including large and complex data types

- gold Open Access which fosters wider collaboration and increased citations

- maximum visibility for your research: over $100 \mathrm{M}$ website views per year

At BMC, research is always in progress.

Learn more biomedcentral.com/submissions 